\title{
3409 大規模ビル内におけるマルチカーエレベータの有効性と その制御方法 Effectiveness and control strategies of multi-car elevators for high-rise
buildings
}

\author{
○非 須藤 事 (フジテック株式会社) \\ 非 マルコン シャンドル (フジテック株式会社) \\ 非 鈴木裕通 (フジテック株式会社) \\ 非 喜多一(大学評価・学位授与機構)
}

Takeshi Sudo, Fujitec Co., Ltd. Hiromichi Suzuki, Fujitec Co., Ltd.

Sandor Markon, Fujitec Co., Ltd. Hajime Kita, National Institution for Academic Degrees

\begin{abstract}
Ropeless linear motor elevators with several cars in each hoistway have been proposed as a way to increase the handling capacity. By allowing both vertical and horizontal movements, cars could circulate or bypass becomes more simple and feasible. However, is achieved. If horizontal movement is not needed, the multi-car system the performance a in is me are many constraints on the car movements, so the performance gain is not evident. In order to investigate effectiveness of and control strategies for such multi-car the resultse have developed a simulator system to analyze multi-car linear motor elevators. This paper reports the results of the simulation study, which show that such systems would have clear advantages.
\end{abstract}

Key Words: Multi-car elevators, linear motors, simulation, genetic algorithm

\section{1 はじめに}

近年，大規模な複合ビル施設や超高層ビルが増え，また従来 をはるかに越える規模の建物も検討されている。このようなビ ルは多くのエレベータが必要となり, その設置面積の增大が問 題視されている $[1]$. この解決策としてロープレスリニアモー ターエレベータが提案されている [2]. その特徴は，1つの昇降 路内を複数のかごが走行できることである.このシステムをワ ンシャフトマルチカーエレベータと呼び, 以後 MCE(Multi-car elevators) と記す. 本稿では筆者らの提案する MCE モデルと その効果を述べ, 制御方法の検討に必要となるシミュレーショ ンと，それをべースにした最適化について述べる。

\section{MCE 提案モデル}

$\mathrm{MCE}$ の運転形態として，文献 [2]等では，ロープレス化によ り可能になる水平方向移動を利用し，非常に効率の良いシステ ムが提案さ机ている。しかし，このような構成は装置が複雑に なり導入面では不利となる，そこで筆者らは，水平方向移動を 行わないFig.1 に示すモデルを提案している [3][4]. 提案モデル は以下の特徵を持つ。

ガレージ階 メインフロアより下にガレージ階を設け, 全ての かごのメインフロアでのサービスを可能とする.

街突回避 MCE では，シャフト内でかご同士が衝突する危険 性がある. 安全性を重視し, 同一シャフト内でかご同士が 互いに向かい合う方向への走行はかご間の間隔によらず禁 止した。

ゾーン運転 通常のエレベータでも高層ビルではゾーン運転が 適用さ机る。ゾーン運転では各エレベータの停止回数が減 り，輸送効率が良くなる．提案方式では同一シャフト内で ゾーン運転を行う。これにより従来エレベータと同様の効 果が得られるとともに，シャフト内でのかご同士の衝突回 避制御が容易になる。

乗り場行き先陼登録方式 乗り場ボタンで上下方向だけでなく， 行き先階を登録させる方式を採用する。こ机は同一シャフ トでもかごによってサービスゾーンが異なるので，あらか じめ行き先階を指定する必要があることによる。

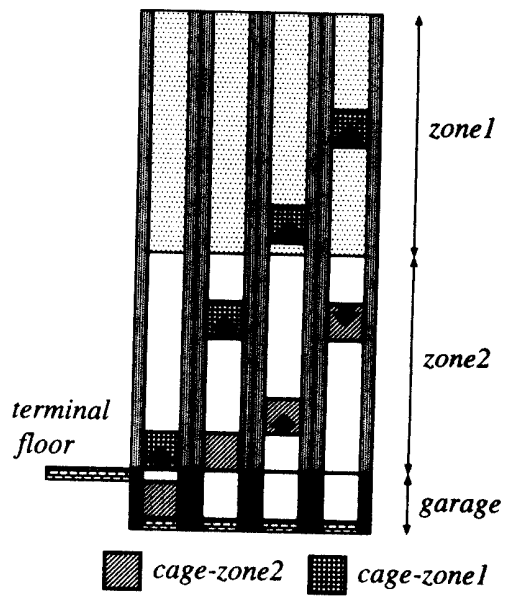

Fig.1: Proposed multi-car system

\section{MCE シミュレーション}

MCE の制御方法を詳細に検討するために，新たに開発した 沉用離散事象シミュレータ䅺築ツールから，提案する MCE モ デルのシミュレータを構成した [5]. シミュレーションでは乗客 の待ち時間やサービス時間を評価することができる。またより 詳細な挙動の解析にはエレベータの運行線図の表示 (Fig.2)や, アニメーション表示 (Fig.3)を用いる.

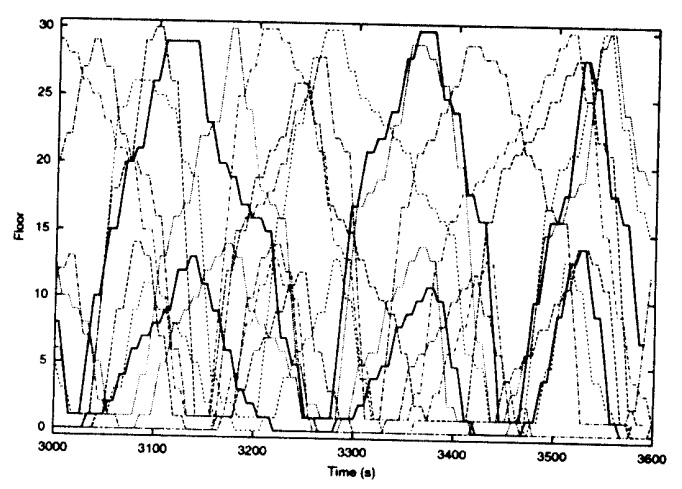

Fig.2: Travel Diagram of MCE Simulation

〔No.02-50〕日本機械学会第 11 回交通・物流部門大会講演論文集〔2002-12.11～13. 川崎〕 


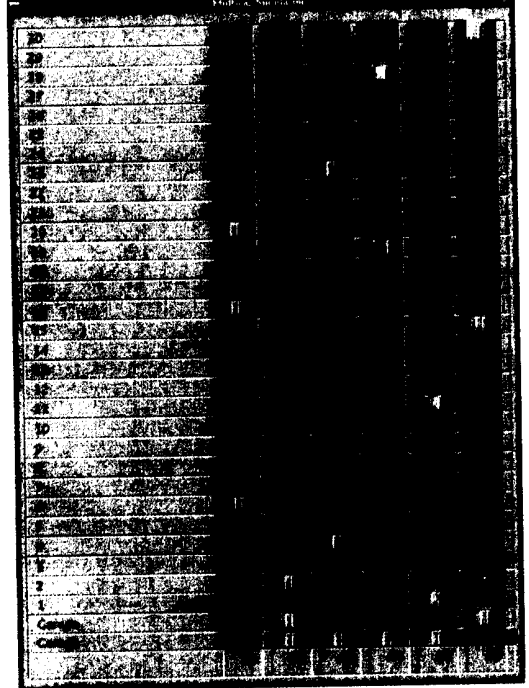

Fig.3: MCE Simulation Display

\section{MCE の性能検証}

$\mathrm{MCE}$ の性能検討として, 30 階床のビル, 出勤時間帯の交通 で MCE シミュレーションを, 昇降路内のかご台数を変化させ ながら実行した。制御方策はヒューリスティクスである，従来 型エレベー夕(分割急行運転) と昇降路内かご台数が $2,3,4$ 台の MCE について, 乗客の発生率と平均待ち時間との関係を Fig.4 に示す。またTable 1 には平均待ち時間を 30 秒とした時 の輸送能力を示す。シャフト内かご台数が 2 台では従来型と差 はないものの, 3 台以上になると輸送能力の上昇が確認できる. それに伴い昇降路面積も従来型の $60 \%$ 以下に削隇できること がわかる.

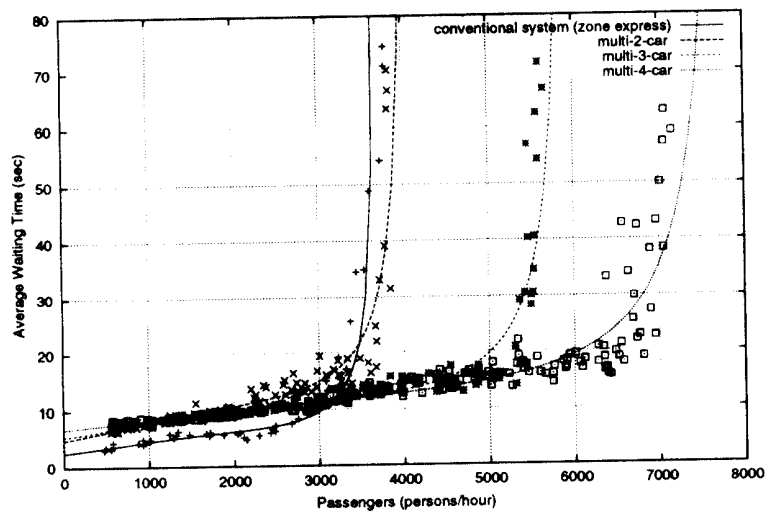

Fig.4: Results of MCE Simulation for a 30-floor building

Table 1: Performance for 30-floor building

\begin{tabular}{|c|c|c|}
\hline $\begin{array}{c}\text { Number of } \\
\text { cars per shaft }\end{array}$ & Persons/hour & Space usage \\
\hline 1 (conventional) & 3600 & 1.00 \\
\hline 2 & 3700 & 0.89 \\
\hline 3 & 5400 & 0.63 \\
\hline 4 & 6600 & 0.53 \\
\hline
\end{tabular}

\section{GA による制御則の最適化}

出勤時間帯の交通は比較的簡単なとューリスティクスの下で 運転可能である。 それ以外の偏りを持った交通では, より柔軟
な制御アルゴリズムが必要となる。そこで，有効性の期待でき る属性值とそ扎らへの荷重パラメータからなる制御則を構成し， そのパラメー夕を交通パターンに応じ，遺伝的アルゴリズムで 最適化した，世代交代モデルには佐藤らによる MGG[6], 交叉 には小野らによるUNDX[7] を用い, 評価関数值は乱数の種を 変えた 5 回のシミュレーション結果の平均値である. Fig.5に 平常時をモデル化した交通における，最適化前の制御及び最適 化後の制御則で実行したシミュレーション結果を示す。高負荷 での平均待ち時間が改善され，輸送能力が向上していることが わかる.

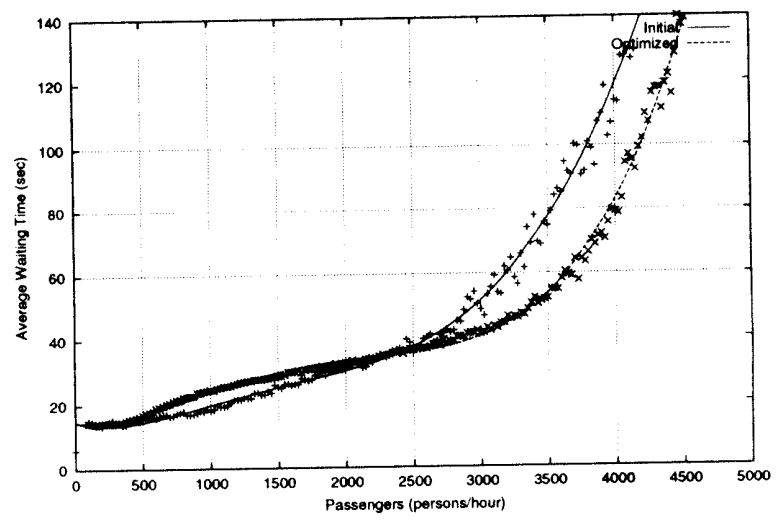

Fig.5: Performance of the optimized controller

\section{6 おわりに}

本稿では，MCE システムの提案，その有効性を評価するため のシミュレータの構成, シミュレーションを通じた制御ルール の最適化を行った. 今後は, 現在の固定ゾーン運転を廃し、ゾー ン境界自体も最適化対象にする等，より柔軟かつ頑強な制御則 の構築を目指す。

\section{参考文献}

[1] 湯村, 岩田, 桑田, 荒木：ロープ式ダブルカーエレベーター の基礎技術開発制御の研究, 昇降機・遊戯施設等の最近の技 術と進歩技術譜演会講演論文集, pp.21-24, 2002

[2] 宮武, 古関, 曽根：ロープレスエレベータシステムの提案 とその有効性評価, 電学論 D, 119 巻 11 号, pp.1353-1360, 1999

[3] T. Sudo, S. Markon: The Performance of Multi-Car Linear Motor Elevators, Elevator Technology 11 Proceedings of ELEVCON 2001, pp.141-149, 2001

[4] 喜多, マルコン, 須藤, 鈴木：ワンシャフトマルチカーエレ ベータの運行制御の研究, 第 14 回自律分散システム・シンポ ジウム資料, pp.63-66, 2002

[5] 須藤, マルコン, 喜多, 鈴木：エージェント指向の離散 事象シミュレーション, 第 25 回システム工学部会研究会, pp.97-102, 2002

[6] 佐藤, 小野, 小林：遺伝的アルゴリズムに置ける世代交代モデ ルの提案と評価, 人口知能学会誌, Vol.12, No.5, pp.734-744, 1997

[7] I. Ono, S. Kobayashi: A Real-coded Genetic Algorithm for Function Optimization Using Unimodal Normal Distribution Crossover, Proc.7th ICGA, pp.246-253, 1997 デル の提案と評価, 人口知能学会誌, Vol.12, No.5, pp.734-744, 1997 